\title{
ЛОГІКА ВИКОРИСТАННЯ ПОРТФОЛІО В ЗАБЕЗПЕЧЕННІ ЯКОСТІ ПІСЛЯДИПЛОМНОЇ МЕДИЧНОЇ ОСВІТИ ТА БЕЗПЕРЕРВНОГО ПРОФЕСІЙНОГО РОЗВИТКУ ЛІКАРЯ. АНАЛІТИЧНИЙ ОГЛЯД
}

\author{
Ю. В. Вороненко, О. П. Мінцер \\ Національна медична академія післядипломної освіти імені П. Л. Шупика
}

\begin{abstract}
Розглядається проблема використання портороліо як особистісно-орієнтована технологія підвищення якості медичної освіти. Підкреслюється, що інструментарій «Портфоліо» $є$ в даний час ефективним засобом об'єктивізації і кількісного визначення освітнього й професійного зростання в освіті та безперервному професійному розвитку лікаря. Воно може використовуватися й для оцінювання соціальних відносин і компетенцій, що важко оцінити іншими способами. Портороліо може широко застосовуватися для демонстрації набуття компетенцій по міждисциплінарним і трансдисциплінарним напрямам медицини, а також засвоєння неклінічних навиків.

Також акцентовано увагу на те, що технологія портороліо в післядипломній медичній освіті може бути використана для підтримки редрлексивної практики лікаря, управління знаннями та управління передаванням знань на організаційному та індивідуальному рівнях. Проте, створення е-портфоліо вимагає глобальної гармонізації контентів навчання, профресійної діяльності й оцінювання вдосконалення лікаря в професійних умовах.
\end{abstract}

Ключові слова: портфоліо, післядипломна медична освіта, безперервний професійний розвиток, якість освіти, оцінювання компетенцій лікаря, піраміда Міллера, е-портфоліо, надійність портфоліо.

\section{THE LOGIC OF USING THE PORTFOLIO IN ENSURING THE QUALITY OF POSTGRADUATE MEDICAL EDUCATION AND CONTINUOUS PROFESSIONAL DEVELOPMENT OF THE DOCTOR. ANALYTICAL REVIEW}

\author{
Yu. V. Voronenko, O. P. Mintser \\ Shupyk National Medical Academy of Postgraduate Education
}

The problem of using the portfolio as a personal oriented technology for improving the quality of medical education is considered. It is emphasized that the "Portfolio" is currently an effective tool for objectifying and quantifying educational and professional growth in education and continuous professional development of the doctor. It can also be used to assess social relations and competencies that are difficult to assess in other ways. Portfolio can be widely used to demonstrate the acquisition of competences in interdisciplinary and transdisciplinary areas of medicine, as well as the development of non-clinical skills.

Attention is also focused on the fact that the portfolio in postgraduate medical education is applicable to support the physician's reflexive practice, knowledge management and knowledge transfer management at the organizational and individual levels. However, the creation of an e-portfolio requires a global harmonization of the content of training, professional activity and assessment of the improvement of the doctor in professional conditions.

Key words: portfolio, postgraduate medical education, continuous professional development, quality of education, assessment of doctor's competencies, Miller's pyramid, e-portfolio, portfolio reliability. 


\title{
ЛОГИКА ИСПОЛЬЗОВАНИЯ ПОРТФОЛИО В ОБЕСПЕЧЕНИИ КАЧЕСТВА ПОСЛЕДИПЛОМНОГО МЕДИЦИНСКОГО ОБРАЗОВАНИЯ И НЕПРЕРЫВНОГО ПРОФЕССИОНАЛЬНОГО РАЗВИТИЯ ВРАЧА. АНАЛИТИЧЕСКИЙ ОБЗОР
}

\author{
Ю. В. Вороненко, О. П. Минцер \\ Национальная медицинская академия последипломного обучения имени П. Л. Шупика
}

\begin{abstract}
Рассматривается проблема использования порторолио как личностно-ориентированная технология повышения качества медицинского образования. Подчеркивается, что инструментарий «Портсролио» является в настоящее время эфрфективным средством объективизации и количественного определения образовательного и профессионального роста в образовании и непрерывном профессиональном развитии врача. Оно может использоваться и для оценивания социальных отношений и компетенций, которые трудно оценить другими способами. Портфолио может широко использоваться для демонстрации приобретения компетенций по междисциплинарным и трансдисциплинарным направлениям медицины, а также освоения неклинических навыков.

Также акцентируется внимание на том, что технология портфолио в последипломном медицинском образовании применима для поддержки рефрлексивной практики врача, управления знаниями и управления передачей знаний на организационном и индивидуальном уровнях. Однако, создание е-портфолио требует глобальной гармонизации контентов обучения, профессиональной деятельности и оценки совершенствования врача в профессиональных условиях.
\end{abstract}

Ключевые слова: портоолио, последипломное медицинское образование, непрерывное профессиональное развитие, качество образования, оценка компетенций врача, пирамида Миллера, е-порторолио, надежность портфолио.

Вступ. Ідея використання портфоліо для оцінювання якості навчання в медичній освіті розглядалася як частина переходу від процедури іспитів (отримання серії моментальних зрізів знань — «snapshot») до більш об’ємних методів вимірювання якості освітнього процесу. Передбачалося, що ця форма оцінювання завдяки широкому використанню зворотного зв'язку сприятиме більш високій кореляції між оціночними характеристиками при тестових процедурах і якістю навчання. Вважалося також, що використання портфоліо поліпшить процедуру визначення рівня знань суб'єкту навчання в широкому спектрі медичних областей, які важко оцінити традиційними методами через виражений обсяг клінічних контекстів і велику кількість врахованих параметрів, що відображають виробничі відносини, особистісні якості, рефлексію та професіоналізм [3].

Технологія створення портфоліо лежить в основі освітньої технології, що забезпечує особистісноорієнтований підхід в освіті. Позитивним моментом в інноваційному методі «Портфоліо» $€$ те, що він спрямований безпосередньо на взаємне співробітництво суб'єкту навчання та викладача. Він $€$ одночасно процесом організації, формою та технологією роботи, що дозволяє безперервно оцінювати досягнення суб'єкту навчання, вдосконалюючи процес освіти.

Накопичений досвід застосування механізму «Портфоліо» свідчить про досить складний механізм отримання та використання (найважливіше!) об'ємних і валідних характеристик знань, компетенцій і вмінь лікаря.

Мета дослідження: обгрунтувати тенденції застосування технології «Портфоліо» в післядипломній медичній освіті та безперервному професійному розвитку лікарів і провізорів.

Результати та їх обговорення. Логіка використання портфоліо повинна враховувати схеми занесення інформації, принципи первинного та вторинного оброблення інформації, умови зберігання та видачі даних, а також стратегію використання отриманих висновків для оцінювання знань і професійної майстерності конкретного лікаря чи провізора. Відповідно, огляд накопиченого досвіду щодо застосування портфоліо буде проводитися окремими та структурованими модулями.

Модуль 1. Формальна схема створення портфоліо. Загального чіткого визначення терміну «портфоліо» немає, під цим поняттям розуміють і альбом із фотографіями, картинами, будь-якими творами мистецтва, створеними конкретним фахівцем, або, взагалі «колекцію у певній галузі». В тлумачних словниках можна зустріти таке визначення портфоліо: «Набір документів, зразків робіт, фотографій тощо, що характеризує кого-небудь як фахівця в тій чи іншій галузі та $є$ необхідним при укладанні ділових контрактів при прийомі на роботу тощо» [5]. 
K. Варвус описує портфоліо як «систематичний і спеціально організований збір доказів, що використовується... для моніторингу знань, навиків і відносин суб'єкта навчання» [2].

В освіті портфоліо - форма безперервного оцінювання в процесі безперервної освіти. Передбачається, що навчальне портфоліо можна легко інтерпретувати в професійних і службових оцінках [6].

Портфоліо все частіше використовують у післядипломній медичній освіті в процедурах атестації, прийомі на роботу тощо, як інструмент оцінювання знань на основі документального підтвердження компетентності, базу даних про виконання різних процедур, даних про навчання й інших процедур підвищення професійного та навчального характеру [21].

У новій інтерпретації під портфоліо розуміють веб-технологію, орієнтовану на відображення навчальних або професійних успіхів спеціаліста [15].

Портфоліо вигідно тим, що воно може дозволити вимірювати соціальні характеристики та процеси, які важко оцінити, — такі як професіоналізм, безперервний професійний розвиток, систему відносин і критичне мислення. Портфоліо можна розглядати й для стимулювання більш ефективного навчання шляхом заохочення міждисциплінарного та трансдисциплінарного навчання, забезпечення безперервного оцінювання діяльності. Оцінювання, засноване на діяльності, забезпечує оцінку реального життя спеціаліста в реальних життєвих ситуаціях. Важливо, що відстеження життєвого шляху лікаря допомагає виявити прогалини в навчанні людини. Зворотний зв'язок може бути забезпечений після отримання індивідуальних оцінок і розгляду документа в цілому. Зрозуміло, підсумкова оцінка повинна бути уніфікованою та прийнятною для використання в різних освітніх і професійних структурах [17].

Модуль 2. Використовувані технології оцінювання інформації. Питання визначення, вимірювання та оцінювання рівня сформованості у лікарів компетенцій, знань, умінь, навиків натепер є одними з центральних у практиці навчання.

Серед загальних вимог до системи оцінювання досягнення запланованих результатів провідним $\epsilon$ критеріально-орієнтований підхід. Отже, і портфоліо повинно будуватися на критеріальній основі. Це означає, що оцінювання даних портфоліо відбувається, тільки якщо встановлено критерії в цілому та для кожної його окремої складової. Зауважимо, що окремої уваги заслуговує питання про відповідність, коректність та точність руху до мети.

Технології оцінювання діяльності лікаря за досліджуваний період можна розділити на кілька рівнів. У цьому огляді надамо лише приклади оцінювання двох рівнів: освітнього процесу та функціонування лікаря як спеціаліста та як особистості.

2.1. Алгоритми першого рівня. На першому рівні розглядаються характеристики навчальних процедур. M. H. Davis i G. G. Ponnamperuma (2006) пропонують п’ять кроків у процесі оцінювання даних, що вносяться до портфоліо стосовно навчальних процедур. Вони полягають в аналізі матеріалів доказів навчання; результатів навчання; оцінюванні доказів експертами; особистісному захисті доказів; спільному рішенні про оцінку [13]. Зрозуміло, що експерти, які беруть участь, повинні прийняти рішення, засноване на заздалегідь визначених умовах.

Найвідоміші моделі, що структурують і стандартизують інформацію, отриману з портфоліо, - це піраміда Міллера (Miller’s pyramid), таксономія Блума (Bloom's taxonomy) та модель SMART [16].

Піраміда Міллера (Miller’s pyramid). Загальна піраміда Міллера (Miller G. Е.) запропонована в 1990 році як формуюча рамка для планування й оцінювання результатів клінічного навчання. Піраміда має чотири рівні (рис. 1), що відображають стадійність формування професійної компетентності лікаря. Суть цих рівнів: «знає», «знає як», «показує як», «робить». Зауважимо, що піраміда Міллера часто використовується як модель для оцінювання клінічної компетентності.

Автор моделі відносив до компетенцій рівень «знає як», але останніми роками, відповідно до думок провідних спеціалістів медичної освіти, оцінювання компетенцій у структурі вищої медичної освіти вимагає демонстрації на рівні «показує яК» [27].

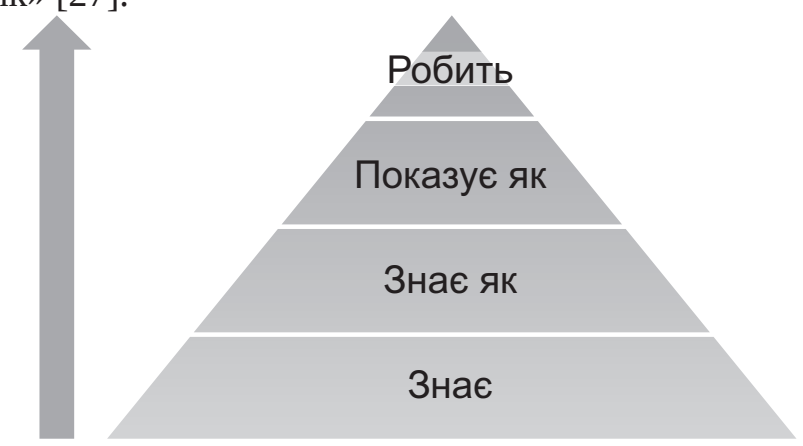

Рис. 1. Піраміда Міллера 
Оцінка першого рівня («знає») піраміди Міллера націлена на підтвердження того, що лікар отримав знання, необхідні для виконання професійних обов'язків. Як метод оцінювання знань здебільшого використовують різні варіанти тестування. Слід підкреслити, що успішна атестація на даному рівні не може відображати реальної готовності кандидата до професійної діяльності.

На другому рівні («знає як») необхідно підтвердити, що лікар може застосовувати наявні знання для вирішення клінічних завдань (рівень когнітивних умінь). Як методи оцінювання можуть бути використані тестові завдання розширеного вибору [7], клінічні ситуаційні задачі, співбесіда та інші.

3 огляду на те, що успішне виконання тестових i письмових завдань не є прямим доказом того, як саме діятиме лікар у реальній клінічній практиці, необхідна демонстрація його готовності виконувати професійні обов'язки, що відповідає третьому рівню піраміди - «показує як». Цей рівень відповідає практичним умінням, навикам і компетенціям в умовах симуляції і для атестації вимагає використання різноманітних імітаційних технологій, що в більшості країн світу об’єднані в об’єктивний структурований клінічний іспит [4].

Останній рівень («робить») характеризує самостійну незалежну практику в реальних клінічних умовах.

Таксономія Блума. Таксономія (від грецького taxis - розташування, лад, порядок i nomos закон) - теорія класифікації і систематизації складно організованих областей дійсності. Була використана Б. Блумом [25] для впорядкування педагогічних цілей із трьох областей освіти когнітивної (вимоги до засвоєння змісту предмета), психомоторної (розвиток рухової, нервово-м'язової діяльності) й афективної (емоційно-ціннісна область, ставлення до досліджуваного). В портфоліо найчастіше використовують першу. Вона включає в себе шість категорій цілей із більш дробовим внутрішнім розподілом: знання (конкретного матеріалу, термінології, фактів, визначень, критеріїв тощо); розуміння (пояснення, інтерпретація, екстраполяція); застосування; аналіз (взаємозв'язків, принципів побудови); синтез (розроблення плану та можливої системи дій, отримання системи абстрактних відносин); оцінювання (судження на основі наявних даних, судження на основі зовнішніх критеріїв).
Таксономія дозволяє забезпечити усвідомлене навчання. Однак, цілі задаються поняттями та не мотивують діяльність, що не визначена як процес на рівні контенту, а кількісні оцінки все ж носять експертний характер. Із введенням освітнього стандарту, що містить вимоги до результатів навчання, робиться спроба ввести критеріальноорієнтований підхід до оцінювання досягнень стандарту. Цей підхід використовується в підсумковому контролі знань, при переході з одного ступеня навчання до іншого, на основі рівня засвоєння навчального матеріалу [23].

Смарт-освіта. Останніми роками стрімко почала розвиватися смарт-освіта — об'єднання навчальних закладів для спільної освітньої діяльності в мережі Інтернет на базі загальних стандартів, угод, технологій і єдиного репозиторія навчальних матеріалів. Прикладом тому може служити проект Єдиного європейського університету з загальним деканатом, що здійснюватиме колективний процес навчання, переміщаючи студентів від вишу до вишу. Отже, смарт-освіта - це гнучке навчання в інтерактивному освітньому середовищі за допомогою єдиного загальносвітового контенту, що знаходиться у вільному доступі та забезпечує широку доступність знань. Проект Єдиного європейського університету повинен бути реалізований у наступному десятилітті.

Взагалі акронім SMART (крім прямого сенсу слова - розумна мета) об'єднує перші літери англійських слів, що позначають, якою має бути справжня мета: specific (конкретна) - measurable (вимірювана) - attainable (досяжна) - relevant (релевантна) - time-bounded (визначена у часі).

Технологія зарекомендувала себе в багатьох областях виробничої та наукової діяльності людини та надає відчутний ефект у повсякденному житті як швидке освоєння і досягнення поставленої мети.

Очевидно, що в основі смарт-навчання лежить дистанційне навчання, що проводиться у вузько направленому форматі або як масовий відкритий онлайн-курс (massive open online course). Останній, зазвичай, $€$ Інтернет-курсом з інтерактивною участю та відкритим доступом для великої кількості суб'єктів навчання [8].

Питання відображення успіхів освоєння знань і компетенцій у портфоліо при смарт-навчанні на загальну думку не $є$ складним. Навпаки, завдяки структуризації навчального матеріалу та впровадженню стандартів автоматизованих навчальних систем (LMS) обсяги й якість засвоєння легко 
вкладаються не тільки в прийняті схеми освіти, а й забезпечують відображення індивідуалізованої підготовки.

2.2. Алгоритми другого рівня. Для оцінювання практичних навиків, знання технологій також описано безліч технологій. Застосовують методи: «оцінювання 360», відеоспостереження, стандартизовані процедури. Навчання й атестація на даному рівні найчастіше реалізуються в програмах інтернатури та ординатури, а також у структурі безперервної медичної освіти.

Методи оцінювання «360 градусів» $\mathbf{i}$ «540 градусів» було запропоновано П. Уордом у 1987 році як методики систематизованого збору інформації про результати діяльності окремих людей або груп і її оцінювання оточенням [9]. Суть методик полягає в тому, що оцінювання працівника здійснює все його робоче оточення: керівники, підлеглі, колеги та клієнти. Оцінюється міра відповідності роботи (в даному випадку лікаря) за списком компетенцій. Результат оцінювання представляє собою рейтинг властивостей працівника [9]. Завдяки блоку самооцінки дані методики можуть бути використані як джерело зворотного зв’язку. Якщо до оцінювання приєднуються інші зацікавлені особи (споживачі, клієнти, партнери), то метод «360 градусів» трансформується в метод «540 градусів». Експерти виставляють бали за компетенціями в спеціальних анкетах. Анкетування може проводитися анонімно з зазначенням категорії експерта (колега, керівник, клієнт). Потім розраховується середнє арифметичне значення по кожній компетенції та вибудовується графік компетенцій. На останньому етапі результати оцінювання представляють самому оцінюваному працівнику. В результаті оцінювання за методом «360 градусів» можуть бути зроблені висновки для саморозвитку працівника, для розвитку компетенцій, поліпшення відносин із колегами, а також прийняті рішення про навчання, підвищення кваліфікації працівника, підвищення / зниження за посадою та інше.

Зазвичай опитування оточення працівника проводиться анонімно. Дослідження встановили, що в разі не анонімного опитування кореляція з незалежними оціночними результатами працівників становила менше 0,1 та була не достовірною. У варіанті «деяка анонімність», де оцінювання комбінується з однією з інших методик, кореляція з незалежними оцінками інших працівників становить до 0,3. Відповідно при максимумі анонімності достовірна кореляція досягає величин 0,7 і вище.
Гарантувати анонімність можна двома способами: проводити оцінювання за допомогою автоматизованої системи, коли всі відповіді обробляються без зазначення індивідуальних результатів; використовувати спеціальні ящики для заповнених анкет, які повинні бути заповнені так, щоб виключити можливість порівняння почерків [9].

Метод «360 градусів» зазвичай застосовують в комплексі з іншими методами оцінювання персоналу, оскільки значною мірою він є суб’єктивним. Слід враховувати й те, що процедура оцінювання супроводжується певним стресом, тому часте використання даного методу небажано [10].

Модуль 3. Доцільність використання портфоліо. Спочатку портфоліо застосовували в медичній освіті для формування цілей навчання, стимулювання методів удосконалення підходів для передавання знань [22]. Відносно недавно використання портфоліо було запропоновано для формування інтегральних цілей освіти. Так, у даний час «е-портфоліо» у Великій Британії є основою як для навчання протягом перших років підготовки лікарів, так і для загальної стратегії підготовки спеціалістів [15]. Воно також складає основу щорічного оцінювання лікарів-стажерів (Annual Review of Competence Progression - ARCP). Оцінений на місцях проходження практики, щорічній документ створює якісне уявлення про продуктивність у навчанні. Зауважимо, що документи, які збираються в е-портфолио для стажерів, переглядаються принаймні кожні 12 місяців у щорічному огляді прогресу в сфері компетенції [28, 29].

Портфоліо широко використовують при навчанні як спосіб документування клінічної компетентності, для реєстрації особистих якостей і компетентностей у конкретній галузі медицини. В 2001 році загальна медична рада дозволила використання портфоліо при повторній атестації лікарів і вже в 2012 році в Об’єднаному Королівстві практично всі ліцензовані лікарі пред’являли портфоліо як доказ своєї практики [28].

Очікується, що для навчання британських стажерів ряду дисциплін будуть документуватися в одній базі даних усі характеристики навчальних процедур та оцінювання їх роботи під час навчання. Стажер вважатиметься компетентним за досягнення ним певних заздалегідь визначених критеріїв, викладених у е-портфоліо. Зауважимо, що подібна документація доступна і для викладачів [15, 28].

Портфоліо часто використовують у післядипломній медичній освіті для отримання кількісної 
оцінки здатності до досягнення успіху [21]. Дійсно, маючи кількісні характеристики професійного зростання лікаря, можна об’єктивізувати процедуру вибору спеціалістів для зайняття певних посад.

Портфоліо є формою аутентичного оцінювання освітніх результатів за продуктом, створеним суб'єктом навчання в ході навчальної, творчої, соціальної та інших видів діяльності [1]. Отже, портфоліо відповідає цілям, завданням і ідеології практико-орієнтованого навчання. Як накопичувальна оцінка портфоліо відображає стійкі та довготривалі освітні результати, компенсуючи ефект випадкового успіху чи неуспіху в ситуації іспиту, тестування. Крім того, він може служити альтернативою «натаскуванню», спровокованому цією ситуацією, що дає короткостроковий і поверхневий результат.

Модуль 4. Оцінка достовірності та надійності використання портфоліо лікаря для оцінювання його професійного зростання. Систематичний огляд доказів надійності використання портфоліо в медичній літературі [17] свідчить, що цей показник за належної організації процесу характеризується високими величинами, проте в ряді випадків може бути і вельми низьким.

Широко використовується заснована на аргументах система Кейна. Вона ідентифікує чотири висновки в аргументі обгрунтування: підрахунок обсягів діяльності (в балах); узагальнення якості проведеної роботи; екстраполяція отриманих результатів для обгрунтування можливості функціонування суб'єкту навчання як спеціаліста та можливі ризики (наслідки). Докази повинні збиратися для підтримки кожного з цих висновків і фокусуватися на найбільш сумнівних припущеннях в ланцюжку висновків. Основні допущення (і необхідні докази) розрізняються залежно від передбачуваного застосування чи пов'язаного з ним рішення.

Вважають, що систему Кейна краще застосовувати до кількісного та якісного оцінювання, а також до індивідуальних випробувань і програм. Цікаво, що найбільше джерело відмінностей спостерігається на рівні експертів факультетів. Беручи до уваги цей факт, у різних дослідженнях рекомендується проводити подібне вимірювання двома або більшою кількістю експертів [11]. Результати, зазвичай, підтримують цілісну оцінку, але аналітичні оцінки заслуговують на подальше вивчення.

Кореляційний аналіз між студентськими портфоліо та традиційними заходами з оцінювання студентської компетентності, а також готовністю до видачі ліцензії дає невисокі, але достовірні коефіцієнти кореляції: $\mathrm{r}=0,32, \mathrm{p}<0,01$. Невеликі та незначущі кореляції спостерігаються між даними портфоліо і середнім показником балів під час навчання та балом на іспиті. В інших дослідженнях ці коефіцієнти кореляції досягають значень 0,92. Окремі компоненти портфоліо, проте, дуже варіюють, що змушує дослідників давати додаткові рекомендації щодо поліпшення структури портфоліо [17].

Відповідно до заснованого на аргументах підходу до обгрунтованості інтерпретації та використання тестових оцінок можна вважати висновки аналізу даних портфоліо дійсними. І навпаки, інтерпретації або застосування, що недостатньо чітко визначені або що пов'язані з сумнівними висновками або припущеннями, не вважають дійсними. Слід підкреслити, що обгрунтованість пропонованої інтерпретації повинна бути оцінена також із точки зору повноти, узгодженості та правдоподібності її висновків і припущень.

Другий аргумент - показник достовірності інформації портфоліо - оцінюється за допомогою коефіцієнтів правдоподібності. Заснований на аргументах підхід забезпечує явне, хоча й умовне, керівництво для перевірки. Наприклад, якщо інтерпретація включає передбачення про майбутні результати, то необхідні докази, які вказують на те, що передбачення точні, але якщо таких прогнозів не зроблено, такого роду передбачувані дані по суті не мають значення.

Передбачається, що для досягнення високого рівня надійності потрібно добре підготувати студентів і лікарів до використання портфоліо. Крім того, портфоліо повинно мати єдиний контент. Очевидно, що й експерти мають бути добре навченими та досвідченими, використовувати чіткі критерії. Всі учасники повинні мати спільне розуміння мети оцінювання [17].

Портфоліо можуть включати в себе інші оцінки, наприклад, в аспірантурі такі, як Direct Observation of Procedural Skills (DOPS) - безпосередньо спостережувані процедурні навики, зворотний зв'язок із декількома джерелами. Дослідження узагальненості показали, що специфічність змісту $€$ основним фактором ненадійності [24]. Це означає, що великі зразки продуктивності повинні бути протестовані до того, як буде отримано достовірну думку про здатність [17] та завдяки включенню оцінок роботи в портфоліо надійність суттєво підвищується. 


\section{Висновки.}

1. Інструментарій «Портфоліо» $€$ в даний час ефективним засобом об’єктивізації і кількісного визначення освітнього та професійного зростання як у самій освіті, так і в безперервному професійному розвитку лікаря. Він може використовуватися й для оцінювання соціальних відносин і компетенцій, що важко оцінити іншими способами.

2. Портфоліо широко використовується для демонстрації компетенцій по міждисциплінарним і трансдисциплінарним напрямам медицини, а також для освоєння неклінічних навиків.

3. Портфоліо в післядипломній медичній освіті застосовуються для підтримки рефлексивної практики лікаря, управління знаннями та управління передаванням знань на організаційному та індивідуальному рівнях.

4. Створення е-портфоліо вимагає глобальної гармонізації контентів навчання, професійної діяльності й оцінювання вдосконалення лікаря в професійних умовах.

\section{Література.}

1. Гетьман Н. А. Аутентичные способы оценивания учебных достижений студентов медицинского вуза / Н. А. Гетьман, Е. Н. Котенко, О. А. Петрухина // Педагогическое образование в России. — 2015. № 1. - C. 22-24.

2. Гетьман Н. А. Портфолио как современная технология оценивания учебных достижений студентов / Н. А. Гетьман, Е. Н. Котенко // Педагогическое образование в России. — 2014. — № 2. - С. 22-28.

3. Гривенная Е. Н. Портфолио-технология в контексте современных систем оценки научно-педагогической деятельности профессорско-преподавательского состава высшего учебного заведения / Е. Н. Гривенная // Общество и право - 2013. - № 3. С. 273-276.

4. Звонников В. И. Контроль качества обучения при аттестации. Компетентностный подход / В. И. Звонников, М. Б. Челышкова. - М. : Логос, 2009. - 272 с.

5. Крысин Л. П. Толковый словарь иноязычных слов / Л. П. Крысин. - М. : Эксмо, 2008. - 944 с.

6. Нестеров А. В. О непрерывном профессиональном образовании / А. В. Нестеров // Компетентность. 2012. — № 2 (93) - C. 4-11.

7. Прокопьева Н. В. Лекция 2. Результаты обучения. Уровни усвоения учебного материала / Н. В. Прокопьева. - КГПУ, 2007. - 14 с.

8. Славин Б. Б. Закат университетов [Электронный ресурс] / Б. Б. Славин // АйТи. — Режим доступу : http://www.it.ru/press_center/blog/4967/
9. Уорд П. Метод 360 градусов / П. Уорд ; пер. с англ. M. : НIPPO, 2006. - 352 с.

10. Эйхингер Р. В. Резюмируем знания по методике «360 градусов» [Электронный ресурс] / P. В. Эйхингер, M. М. Ломбардо // HR-Life. ru. - Режим доступа: http://www.hr-life.ru/article/ rezyumiruem-znaniya-po-metodike-360-gradusov.

11. A contemporary approach to validity arguments: a practical guide to Kane's framework / D. A. Cook, R. Brydges, S. Ginsburg, R. Hatala // Med. Educ. 2015. - Vol. 49, № 6. - P. 560-575.

12. Cooke M. Educating physicians: a call for reform of medical school and residency / M. Cooke, D. M. Irby, B. C. O’Brien. — San Francisco : Jossey-Bass, 2010. — 320 p.

13. Davis M. H. Portfolios, projects and dissertations / M. H. Davis, G. G. Ponnamperuma // J. A. Dent, R. M. Harden (eds.) / A practical guide for medical teachers. — London : Elsevier Churchill Livingstone, 2006. - P. 346-356.

14. Davis M. H. Portfolio assessment in medical students' final examinations / Davis, M. H., Friedman M, Howie P. // Med Teach. — 2001. — № 23. — P. 357-366.

15. E-portfolio [Electronic resource] / The Foundation Programme. - Режим доступу: http://www. foundationprogramme.nhs.uk/pages/home/e-portfolio.

16. Flexner A. Medical education in the United States and Canada / A. Flexner. — New York : The Carnegie foundation for the advancement of teaching, 2010. Bulletin 4. - $364 \mathrm{p}$.

17. Haldane T. «Portfolios» as a method of assessment in medical education / T. Haldane // Gastroenterol. Hepatol. Bed Bench. - 2014. — Vol. 7, № 2. - P. 89-93.

18. JAG Endoscopy Training System [Electronic resource] / JETS. - Режим доступу: http://www.jets.nhs.uk.

19. Jenkins L. Reliability testing of a portfolio assessment tool for postgraduate family medicine training in South Africa / L. Jenkins, B. Mash, A. Derese // Afr. J. Prim. Health Care Fam. Med. — 2013. — Vol. 5, № 1. — P. 577.

20. Kane M. The argument-based approach to validation / M. Kane // School Psychology Review. - Vol. 42, № 4. - P. 448-457.

21. The effectiveness of portfolios for post-graduate assessment and education: BEME Guide No 12 / C. Tochel, A. Haig, A. Hesketh [et al.] // Med Teach. 2009. - Vol. 31, № 4. - P. 299-318.

22. Validity of portfolio assessment: which qualities determine ratings? / E. W. Dreissen, K. Overeem, J. Van Tartwijk [et al.] // Med. Educ. — 2006. — Vol. 40, № 9. - P. 862-866.

23. Ha J. F. Doctor-patient communication: a review // Ha J. F., Longnecker N. // Ochsner J. — 2010. — № 10. — P. 38-43. 
24. Anderson L. W. A taxonomy for learning, teaching, and assessing / Anderson L. W., Krathwohl D. R. - New York: Longman. 2000. - 352 p.

25. Bloom B. S. Taxonomy of educational objectives: The classification of educational goals. Handbook I, cognitive domain / Bloom B. S. — New York: Longman, 1994. - 208 p.

26. Кулакова Е. Н. Результаты обучения будущих педиатров: модели и методы планирования / Кулакова Е. Н., Кондратьева И. В., Волосовец Г. Г. и др. // Современные проблемы науки и образования. 2015. — № 3. - Режим доступу: https://www.scienceeducation.ru/ru/article/view?id=19382.

27. Al-Eraky M. A fresh look at Miller’s pyramid: assessment at the 'Is' and 'Do' levels / Al-Eraky M., Marei H. // Med Educ. — 2016. — № 50 (12). — P. 1253-1257.

28. Режим доступу: http://www.foundationprogramme. nhs.uk/pages/home/e-portfolio.

29. Режим доступу: http://specialtytraining.hee.nhs.uk.

30. Supporting evidence for appraisal and revalidation. London: General Medical Council; 2012. — 16 p.

\section{References.}

1. Get'man, N. A., Kotenko, E. N., \& Petrukhina, O. A. (2015). Autentichnye sposoby otsenivaniya uchebnykh dostizhenii studentov meditsinskogo vuza [Authentic ways of assessing the academic achievements of medical students]. Pedagogicheskoe obrazovanie v Rossii (Pedagogical Education in Russia), 1, 22-24.

2. Get'man, N. A., \& Kotenko, E. N. (2014). Portfolio kak sovremennaya tekhnologiya otsenivaniya uchebnykh dostizhenii studentov [Portfolio as a modern technology for assessing students' academic achievements]. Pedagogicheskoe obrazovanie v Rossii (Pedagogical Education in Russia), 2, 22-28.

3. Grivennaya, E. N. (2013). Portfolio-tekhnologiya v kontekste sovremennykh sistem otsenki nauchnopedagogicheskoi deyatel'nosti professorskoprepodavatel'skogo sostava vysshego uchebnogo zavedeniya [Portfolio-technology in the context of modern systems for assessing the scientific and pedagogical activity of the teaching staff of a higher educational institution]. Obshchestvo i pravo (Society and Law), 3, 273-276.

4. Zvonnikov, V. I. (2009). Kontrol' kachestva obucheniya pri attestatsii. Kompetentnostnyi podkhod [Control of the quality of training in attestation. Competence approach]. Moscow: Logos.

5. Krysin, L. P. (2008). Tolkovyi slovar' inoyazychnykh slov [Explanatory dictionary of foreign words]. Moscow: Eksmo.

6. Nesterov, A. V. (2012). O nepreryvnom professional'nom obrazovanii [On continuing professional education]. Kompetentnost' (Competence), 2(93), 4-11.

7. Prokop'eva, N. V. (2007). Lektsiya 2. Rezul'taty obucheniya. Urovni usvoeniya uchebnogo materiala
[Lecture 2. Learning outcomes. Levels of learning material]. KSPU.

8. Slavin, B. B. (n. d.). Zakat universitetov [Sunset of universities]. AiTi (IT). Retrieved from http://www.it.ru/ press_center/blog/4967/

9. Ward, P. (2006). 360-degree feedback. Moscow: HIPPO.

10. Eichinger, R. W., \& Lombardo, M. M. (n. d.). Rezyumiruem znaniya po metodike «360 gradusov» [Knowledge summary series: 360-degree assessment]. HR-Life.ru. Retrieved from http://www.hr-life.ru/article/ rezyumiruem-znaniya-po-metodike-360-gradusov

11. Cook, D. A., Brydges, R., Ginsburg, S., \& Hatala, R. (2015). A contemporary approach to validity arguments: a practical guide to Kane's framework. Med. Educ., 49(6), 560-575. doi: 10.1111/medu.12678.

12. Cooke, M. D., Irby M., \& O’Brien, B. C. (2010). Educating physicians: a call for reform of medical school and residency. San Francisco: Jossey-Bass.

13. Davis, M. H., Ponnamperuma, G. G. (2006). Portfolios, projects and dissertations. Dent J. A. , Harden R. M. (eds.). A practical guide for medical teachers. London: Elsevier Churchill Livingstone.

14. Davis, M. H., Friedman, M., Howie, P. (2001) Portfolio assessment in medical students' final examinations. Med Teach, 23, 357-366.

15. E-portfolio. The Foundation Programme. Retrieved from http://www.foundationprogramme.nhs.uk/pages/ home/e-portfolio.

16. Flexner, A. Medical education in the United States and Canada. New York: The Carnegie foundation for the advancement of teaching. Bulletin 4.

17. Haldane, T. (2014). «Portfolios» as a method of assessment in medical education. Gastroenterol. Hepatol. Bed Bench., 7(2), 89-93.

18. JAG Endoscopy Training System. JETS. Retrieved from http://www.jets.nhs.uk.

19. Jenkins, L., Mash, B., Derese, A. (2013). Reliability testing of a portfolio assessment tool for postgraduate family medicine training in South Africa. Afr. J. Prim. Health Care Fam. Med., 5(1), 577. doi: 10.4102/phcfm. v5i1.577.

20. Kane, M. (2013). The argument-based approach to validation. School Psychology Review, 42(4), 448-457.

21. Tochel, C., Haig, A, Hesketh, A, Cadzow, A, Beggs, K, Colthart, I, Peacock, H. (2009). The effectiveness of portfolios for post-graduate assessment and education: BEME Guide No 12. Med Teach., 31(4), 299-318. doi: 10.1080/01421590902883056.

22. Driessen, E. W., Overeem, K., van Tartwijk, J, van der Vleuten, C. P., \& A. M. Muijtjens. (2006). Validity of portfolio assessment: which qualities determine ratings? Med. Educ., 40(9), 862-866.

23. Ha, J. F., Longnecker, N. (2010) Doctor-patient communication: a review. Ochsner J, 10, 38-43. 
24. Anderson, L. W., Krathwohl, D. R. (2000). A taxonomy for learning, teaching, and assessing. New York: Longman, 352.

25. Bloom, B. S. (1994) Taxonomy of educational objectives: The classification of educational goals: Handbook I, cognitive domain. New York: Longman, 208.

26. Kulakova, Ye. N., Kondrat'yeva, I. V., Volosovets, G. G. et al. (2015) Rezul'taty obucheniya budushchikh pediatrov: modeli i metody planirovaniya [The results of training for future pediatrics: models and methods of planning] // Sovremennyye problemy nauki i obrazovaniya, 3. Retrieved from: http://www.scienceeducation.ru/ru/article/view?id=19382.

27. Al-Eraky, M., Marei, H. (2016) A fresh look at Miller’s pyramid: assessment at the 'Is' and 'Do' levels. Med Educ. Dec; 50(12), 1253-1257.

28. Retrieved from: http://www.foundationprogramme.nhs. uk/pages/home/e-portfolio

29. Retrieved from: http://specialtytraining.hee.nhs.uk.

30. Supporting evidence for appraisal and revalidation. London: General Medical Council; 2012. Ready for revalidation, 16. 